\title{
Effect of the Use of Curing Salts and of a Starter Culture on the Sensory and Microbiological Characteristics of Homemade Salamis
}

\author{
Cinthia Bittencourt Spricigo* and Patrícia Bonat Pianovsky \\ Pontifícia Universidade Católica do Paraná; Centro de Ciências Exatas e de Tecnologia; Curso de Engenharia de \\ Alimentos; Rua Imaculada Conceição, 1155; 80215-901; Curitiba - PR - Brasil
}

\begin{abstract}
Homemade salamis may have their food safety guaranteed by means of the addition of curing salt and starter cultures, without loosing their traditional manufacturing recipes brought to Brazil by the Italian immigration in the early $20^{\text {th }}$ century. In this work, the influence of curing salt and of a starter culture, composed of Lactobacillus and Staphylococcus, over the sensory and microbiological characteristics of Italian type salamis, containing 3\% lactose and $0.5 \%$ saccharose, was evaluated. The starter culture and the curing salt inhibited the development of Staphylococcus aureus and of coliforms, and the salamis added with curing salt presented better color attributes.
\end{abstract}

Key words: Curing salt, food safety, salami, starter culture

\section{INTRODUCTION}

The homemade salami production started in Brazil as an influence of the Italian immigration in the beginning of the $20^{\text {th }}$ century. Today, besides the industrialization of the product by meat processing plants, the homemade production of salamis is still a profitable activity to families which live on the agriculture, as it adds value to the pork meat. However, the existence of industrial pre-mixes containing seasonings and additives to the production of salami causes the lose of the traditional recipes brought by the Italian immigrants, so that the homemade salamis loose their identity. The return to the original recipes is an important factor to the differentiation of the homemade from the industrial salami, but it must be followed by modern preservation technologies able to guarantee the microbiological safety of the homemade salamis.

Salami is a raw meat product, fermented and dehydrated, that is preserved by means of $\mathrm{pH}$ and water activity reduction. Originally, the meat has a $\mathrm{pH}$ varying from 5.4 to 5.8 (Prändl et al., 1994), and water activity of 0.99 (Dabin and Jussiaux, 1993). Salami has a pH lower than 5.3, due to the fermentation with production of lactic acid, and water activity around 0.90 (Dabin and Jussiaux, 1993), due to the product dehydration and to the presence of salt. Such conditions reduce microbial growing, allowing the product preservation for about three to four months at room temperature. Besides that, the salami still counts with the presence of curing salts, such as sodium nitrite and nitrate, that improve the color of the product. Sodium nitrite, specifically, has an important bacteriostatic action against Clostridium botulinum

\footnotetext{
* Author for correspondence
} 
and a series of pathogenic and putrefactive microorganisms (Prändl et al., 1994; Frey, 1995). The action of sodium nitrite on the predominant meat pigment, the myoglobin, produces an attractive red color in the product and a characteristic aroma (Prändl et al., 1994). Salami may also be added with starter bacterial cultures, which have the function of improving preservation, safety and the sensorial characteristics of the product. The culture acts on the substrate producing the fermentation reactions and inhibiting the grow of spoilage and pathogenic microorganisms (Balduíno, 1999).

In the present work, common carbohydrate sources were employed as the substrate to the starter culture formed by lactic and Microccocaceae bacteria. The aim was to produce salamis with a final $\mathrm{pH}$ of 5.2 after 2 to 5 days of fermentation, so that the product could develop an adequate texture maintaining a slight acidic taste, as the Brazilian consumer appreciates. With the aim of evaluating food safety and the color quality of the salamis microbiological and sensorial analyses were made. An experimental planning was built, with two parameters in two levels: the use or the absence of curing salt and of starter culture. The answers of the experiments are related to the microbiological quality of the product during the maturing period.

The results obtained from the experimental planning were evaluated statistically with base on the influence of the parameters on the answers of the system, as described by Barros Neto et al. (1995). The statistical significance of the results was evaluated based on the standard deviations calculated among the different experimental values, that are related to the experimental variability.

\section{MATERIAL AND METHODS}

\section{Salami preparation}

The procedure was divided into mass preparation, stuffing, fermentation and ripening. The mass preparation was performed by grinding the raw meat in a disc number 7 (model 98BT, C.A.F., Brazil) and by adding the desired proportion of ingredients to the ground meat. Only pork meat was used in this work, namely pork shoulder and belly fat, besides natural garlic, common salt and white pepper. In order to verify the influence of the starter culture (Bactoferm-T-SL, Chr. Hansen, Brazil) and of the curing salt (sodium nitrate and common salt, Dicarne, Brazil) on the color and microbiological characteristics of the product, four formulations were tested, composing an experimental planning of two parameters and two level each (presence or absence of starter culture and of curing salt). The salami formulation employed in this work was: $85 \%$ pork shoulder, $15 \%$ belly fat, $0.5 \%$ natural smashed garlic, $0.1 \%$ powdered white pepper $3 \%$ powdered integral milk and $0.5 \%$ common sugar. After these ingredients were well mixed with the minced meat the pasta was divided into four parts. To each part, the starter culture and the curing salt were added, as indicated in Table 1. Less common salt was added to the pasta when curing salt was added. The use of the curing salt in this work was due to the fact that this ingredient is cheap and easily accessible to the small salami producer.

Table 1 - Quantity of ingredients added to the different tests of the experimental planning.

\begin{tabular}{c|c|c|c}
\hline Tests & T-SL starter culture & Curing salt & Common salt \\
\hline 1 & $0.0125 \%$ & $1 \%$ & $2 \%$ \\
2 & --- & $1 \%$ & $2 \%$ \\
3 & $0.0125 \%$ & --- & $3 \%$ \\
4 & --- & -- & $3 \%$ \\
\hline
\end{tabular}

The stuffing of the pasta was performed in a manual stuffing machine, in cellulose artificial casings of $50 \mathrm{~mm}$ diameter. The stuffed salamis were about $25 \mathrm{~cm}$ long, and were placed in an incubation oven (Model 347F, FANEM, Brazil) at $27^{\circ} \mathrm{C}$ for 2 to 5 days to the fermentation process. Then, the salamis were dehydrated at a temperature of $14^{\circ} \mathrm{C}$ for a period of 21 days (the ripening period). After this, the salamis were vacuum packed and stored at room temperature.

\section{Evaluations of $\mathrm{pH}$ and weight losses}

During the fermentation and ripening periods, salamis were analyzed regarding $\mathrm{pH}$ drop and weight losses. $\mathrm{pH}$ was measured with a calibrated 
potentiometer (B371, MICRONAL, Brazil) through the removal of small samples from the stuffed salamis. Weight losses were measured with the use of an analytical balance (Model AS2000, Marte, Brasil), by weighing identified pieces after specified time intervals. The values were taken, in both cases, as an average between two samples.

\section{Microbiological analyses}

With the aim of evaluating the microbiological quality of salamis up to the end of ripening, analyses of lactic acid bacteria, Staphylococcus aureus, total coliforms, molds and yeasts, Salmonella and sulfite reducer Clostridium were performed (Compendium of Methods for the Microbiological Examination of Foods) as described by Silva and Amstaldem (1997). The microbiological analyses were performed in duplicate incubation plates after 4, 11, 18 and 25 days of the fermentation and ripening periods.

\section{Sensory evaluation}

When ready, salamis prepared with different ingredients were sensory evaluated regarding the color aspect. A multiple comparison test was applied (Dutcosky, 1996) in order to determine the influence of the curing salt and of the starter culture on the color quality of the product. Each sample group presented to the nineteen members of the sensory panel had a standard (salami added with starter culture and curing salt) and four codified samples. The sensory panel attributed values from one to nine to each sample. Grade one corresponded to an evaluation "much better than the standard", and grade nine corresponded to "much worse than the standard".

\section{RESULTS AND DISCUSSION}

Figures 1 and 2 present the results of $\mathrm{pH}$ drop and of weight losses during fermentation and ripening of the salamis. The results of $\mathrm{pH}$ evolution obtained were considered satisfactory, as a significant $\mathrm{pH}$ reduction was obtained around the third to the fifth days of fermentation. However, tests 1 and 3 that were added with starter culture presented a stronger $\mathrm{pH}$ drop, maintaining the difference form tests 2 and 4 until the end of the ripening period, reaching a desirable final $\mathrm{pH}$ value around 5.2. The final $\mathrm{pH}$ values of the tests 2 and 4 were much above the values expected to this kind of product (around 5.2), indicating that the natural lactic acid bacteria were not able to produce a good fermentation result in these cases. Regarding weight losses, all the tests presented similar losses, around $28 \%$ at the end of the ripening period.

The results of the microbiological analyses are presented in Tables 2 to 5 .

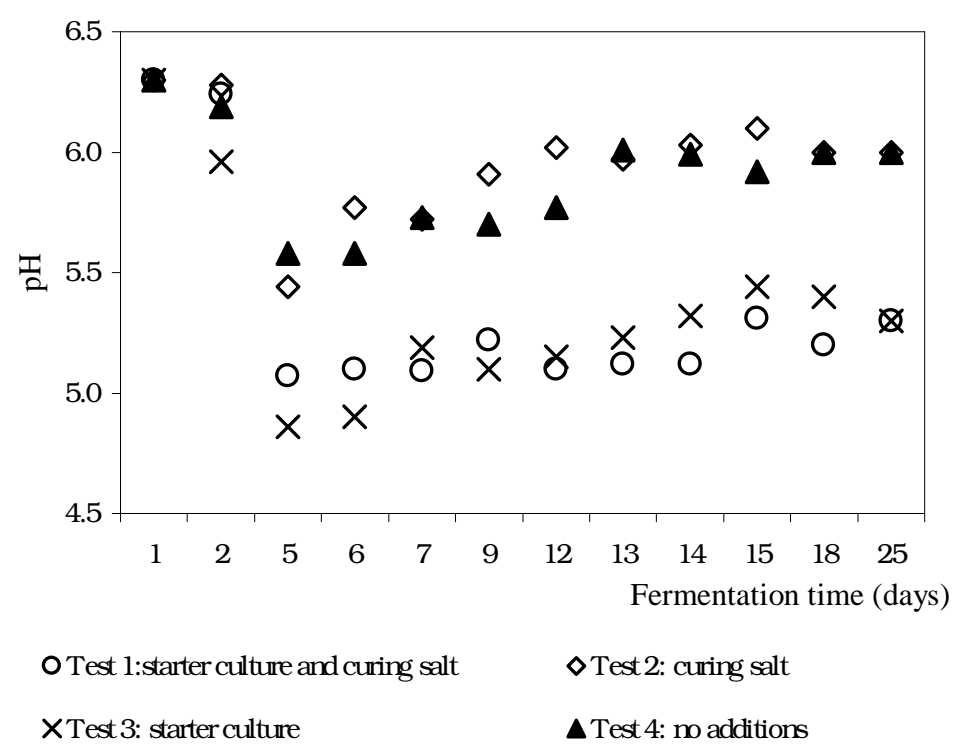

Figure 1 - $\mathrm{pH}$ evolution during the fermentation and ripening periods in the different tests. 


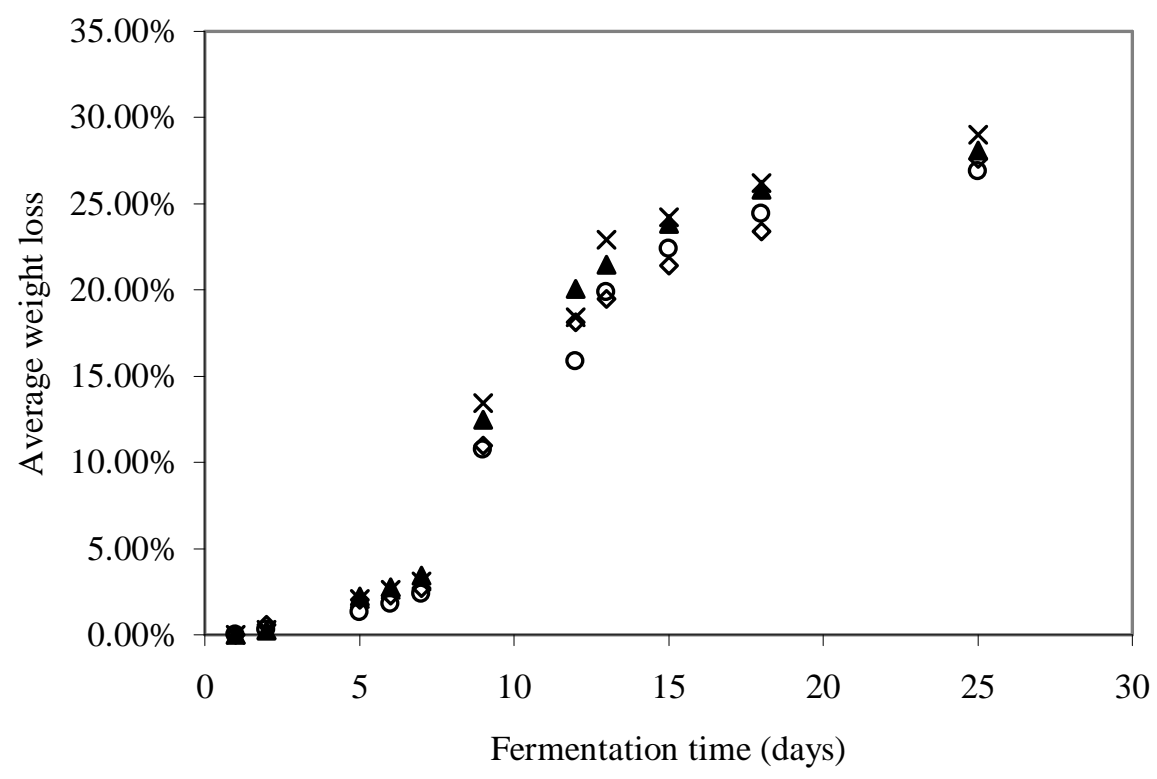

○ Test 1: starter culture and curing salt

$\diamond$ Test 2: curing salt

$\times$ Test 3: starter culture

A Test 4: no additions

Figure 2 - Average accumulated weight losses in the salamis of the different tests.

Table 2 - Average lactic acid bacteria counts.

\begin{tabular}{ccccc}
\hline \multicolumn{2}{c}{ Lactic acid bacteria counts (CFU/g) } & & & Test 4 \\
\hline Ripening time (days) & Test 1 & Test 2 & Test 3 & $1.2 \times 10^{8}$ \\
$4^{\text {th }}$ & $1.1 \times 10^{8}$ & $1.7 \times 10^{8}$ & $2.2 \times 10^{8}$ & $1.7 \times 10^{8}$ \\
$11^{\text {th }}$ & $2.9 \times 10^{7}$ & $7.6 \times 10^{7}$ & $8.5 \times 10^{7}$ & $9.7 \times 10^{7}$ \\
$18^{\text {th }}$ & $4.0 \times 10^{7}$ & $3.9 \times 10^{7}$ & $1.3 \times 10^{8}$ & $1.0 \times 10^{8}$ \\
$25^{\text {th }}$ & $5.4 \times 10^{7}$ & $6.6 \times 10^{7}$ & $4.7 \times 10^{7}$ & 1.0 \\
\hline
\end{tabular}

Table 3 - Average counts of molds and yeast.

\begin{tabular}{cclll}
\hline \multicolumn{2}{c}{ Moulds and yeast } & (CFU/g) & & \\
\hline Ripening time (days) & Test 1 & Test 2 & Test 3 & Test 4 \\
$4^{\text {th }}$ & $1.3 \times 10^{7}$ & $3.6 \times 10^{6}$ & $9.4 \times 10^{6}$ & $3.4 \times 10^{6}$ \\
$11^{\text {th }}$ & $2.7 \times 10^{6}$ & $2.3 \times 10^{6}$ & $1.8 \times 10^{6}$ & $1.2 \times 10^{6}$ \\
$18^{\text {th }}$ & $2.2 \times 10^{7}$ & $8.0 \times 10^{6}$ & $2.0 \times 10^{7}$ & $1.5 \times 10^{7}$ \\
$25^{\text {th }}$ & $8.7 \times 10^{6}$ & $5.7 \times 10^{6}$ & $6.1 \times 10^{6}$ & $3.4 \times 10^{7}$ \\
\hline
\end{tabular}

Table 4 - Staphylococcus aureus counts.

\begin{tabular}{cclll}
\hline \multicolumn{2}{c}{ Staphylococcus aureus } & (CFU/g) & & \\
\hline Ripening time (days) & Test $\mathbf{1}$ & Test 2 & Test 3 & Test 4 \\
$4^{\text {th }}$ & $3.2 \times 10^{3}$ & $4.0 \times 10^{3}$ & $3.8 \times 10^{3}$ & $4.9 \times 10^{3}$ \\
$11^{\text {th }}$ & $4.4 \times 10^{3}$ & $5.1 \times 10^{3}$ & $5.5 \times 10^{3}$ & $7.7 \times 10^{3}$ \\
$18^{\text {th }}$ & $5.0 \times 10^{3}$ & $5.8 \times 10^{3}$ & $3.9 \times 10^{3}$ & $6.2 \times 10^{3}$ \\
$25^{\text {th }}$ & $4.6 \times 10^{3}$ & $5.9 \times 10^{3}$ & $5.7 \times 10^{3}$ & $6.7 \times 10^{3}$ \\
\hline
\end{tabular}


Table 5 - Total coliform analyses.

\begin{tabular}{crrrr}
\hline \multicolumn{2}{c}{ Total Coliform (MPN/g) } & & & \\
\hline Ripening time (days) & Test 1 & Test 2 & Test 3 & Test 4 \\
$4^{\text {th }}$ & 4 & 20 & 28 & 210 \\
$11^{\text {th }}$ & $<3$ & 39 & 210 & $>2400$ \\
$18^{\text {th }}$ & $<3$ & 9 & 460 & $>2400$ \\
$25^{\text {th }}$ & 4 & $<3$ & 9 & 1100 \\
\hline
\end{tabular}

Table 6 - Results of the Dunnett test (minimal significant difference $=0.96$ ).

\begin{tabular}{cccc}
\hline $\begin{array}{c}\text { Average grade of the } \\
\text { standard (Teste 1) }\end{array}$ & $\begin{array}{c}\text { Average grades of the } \\
\text { tests }\end{array}$ & $\begin{array}{c}\text { Difference between } \\
\text { averages }\end{array}$ & Results \\
\hline 4.45 & 5.27 (test 2$)$ & 0.82 & Samples are not different \\
4.45 & 7.18 (test 3) & 2.73 & Samples are different \\
4.45 & 7.09 (test 4) & 2.64 & Samples are different \\
\hline
\end{tabular}

Statistical analyses performed with the results presented in Table 2 indicated that the presence of curing salt was associated with a significant reduction in lactic acid bacteria counts.

The results of the molds and yeast analyses, presented in Table 3 showed that the test 4 that did not have either curing salt or starter culture added, presented a high count on the $25^{\text {th }}$ ripening day, and a tendency of increasingly counts as the ripening process developed. This could result in a shorter shelf life of the product in comparison to salamis added with curing salt and/or starter culture.

Table 4 indicated that only test 1 presented a $S$. aureus count compatible with the legislation requirements to this product $\left(5 \times 10^{3} \mathrm{CFU} / \mathrm{g}\right)$ (Silva and Amstalden, 1997). All the other tests presented at least one value above the legal limit. The presence of curing salt and of starter culture in the salamis significantly influenced the reduction of $S$. aureus counts, increasing the product safety to the consumer.

The legal limit to total coliform in salamis is $10^{3}$ NMP/g (Silva and Amstalden, 1997). As observed from Table 5 only the test 4 surpassed this limit, indicating a lower safety level of salamis prepared without the addition of curing salt and of starter culture. The statistical analyses indicated that the curing salt and the starter culture significantly influenced, together and individually, the reduction in the total coliform counts. The microbiological analyses indicated the absence of Salmonella and of sulfite reducers Clostridium in all the four tests.
After the sensory evaluation of the color of the samples by the sensory panel the results were submitted to a variance analysis (ANOVA) and to the test of Dunnett. The samples were all compared to the standard. The samples from the tests 3 and 4 presented a significant difference from the standard at a 5\% confidence level. The Dunnett test provided a minimal significant difference of 0.96 . Table 6 showed that only the samples 3 and 4 presented values above this minimal significant difference. Both were characterized as possessing a worse color than the standard sample, which was added with curing salt and starter culture. This result indicated that the curing salt influenced significantly the color of the product, making it more attractive to the consumer.

From the results presented in this work it was concluded that the addition of a starter culture was important to control the velocity of fermentation and the final $\mathrm{pH}$ value attained by the product. A correct $\mathrm{pH}$ drop to values around 5.2 after 2 to 5 days of fermentation was desirable for texture development and microbiological safety. The addition of a standard fermentative flora to the pasta favored the maintenance of flavor and color characteristics and controled the action of the microorganisms naturally present in the meat.

\section{ACKNOWLEDGMENTS}

The authors wish to thank PUCPR and PIBIC/CNPQ for the financial and technical support to this work. 


\section{RESUMO}

Os salames produzidos artesanalmente podem ter sua segurança alimentar garantida pela adição de sal de cura e de culturas iniciadoras sem perda das receitas tradicionais trazidas pela imigração italiana do início do século vinte. Neste trabalho, a partir da produção de salames com $3 \%$ de lactose e $0,5 \%$ de sacarose, avaliou-se a influência do sal de cura e da cultura iniciadora, composta de Lactobacillus e Staphylococcus, sobre as características sensoriais e microbiológicas dos salames. A cultura iniciadora e o sal de cura inibiram o crescimento de Staphylococcus aureus e de coliformes totais, sendo que os salames adicionados de sal de cura apresentaram uma melhor coloração.

\section{REFERENCES}

Balduíno, R. (1999), Cultura láctica mista com potencial de aplicação como cultura iniciadora em produtos cárneos. Ciência e Tecnologia de Alimentos, 19, 356-362.

Barros Neto, B; Scarmínio, I. S. and Bruns, R. E. (1995), Planejamento e otimização de experimentos. Campinas : UNICAMP.

Dabin, E. and Jussiaux, R. (1993), Le saucisson sec. Paris : ERTI Éditeur.

Dutcosky, S. D. (1996), Análise sensorial de alimentos. Curitiba : Champagnat.

Frey, W. (1985), Fabricación fiable de embutidos. Zaragoza : Acribia.

Prändl, O.; Fischer, A.; Schmidhofer, T. and Sinell, H. J. (1994), Tecnología e higiene de la carne. Zaragoza : Acribia.

Silva, N. and Amstalden, V. C. (1997), Manual de métodos de análise microbiológica de alimentos. São Paulo : Varela.

Received: September 29, 2004; Revised: February 25, 2005; Accepted: March 25, 2005. 